Dossiê: Conferência de Medellín: 50 anos - Artigo Original (c) (1)

\title{
A Conferência Episcopal de Medellín: inspiração para uma mística latino-americana e caribenha
}

\author{
The Episcopal Conference of Medellín: inspiration for a latin american and \\ caribbean mysticism
}

Carlos Frederico Barboza de Souza*

\begin{abstract}
Resumo
A proposta deste artigo é pensar em uma mística que nasça da inspiração da II Conferência Geral do Episcopado Latino-Americano realizada na cidade de Medellín, Colômbia, no período de 24 de agosto a 6 de setembro de 1968. Após 50 anos deste evento inaugurador de um rosto latino-americano e caribenho da Igreja Católica, com um viés ecumênico e atento aos "sinais dos tempos", desenvolveu-se, também, uma mística singular e vinculada à realidade vivida na América Latina. Neste sentido, este artigo abordará a singularidade da mística que nasce de Medellín e apontará para suas especificidades: uma mística histórica e não dicotômica; integral; compassiva e centrada no serviço, sobretudo, aos empobrecidos; diaconal e vivida no dinamismo do amor; experimentada nas Comunidades de Base; profética e libertadora; pautada em uma leitura engajada da Bíblia; e atenta aos Sinais dos Tempos. Apoiado em um método de revisão bibliográfica e em diálogo com autores que abordam o documento conclusivo da Conferência, em um primeiro momento, este artigo introduzirá a inovação promovida por Medellín, sugerindo-o como um carisma eclesial que pode ser atualizado na realidade contemporânea. Em seguida, abordará as especificidades da mística que nasce naquele momento.
\end{abstract}

Palavras chave: Mística; Diálogo inter-religioso; Conferência Episcopal de Medellín.

\begin{abstract}
This article's proposal is to think in a mysticism from the inspiration of the Second General Conference of the Latin American Episcopate that was held in Medellín, Colombia, between 24th August and 6th September of 1968. From 50 years of this inaugural event of a Latin American and Caribbean face of the Catholic Church, with an ecumenical perspective and attentive to the "Signs of the Times", has developed, also, a singular mysticism, linked with the reality lived in Latin America. In this way, this article will approach the singularity of this mysticism, that was born in Medellín and will point for their specificities: an historical and no dichotomyc mysticism; integral; compassionate and centered in the service, mainly to the poors; diaconal and lived in the dynamism of love; experienced in the Basis Communities; prophetic and liberating; ruled in an engaged reading of the Bible; and attentive to the Signs of the Times. Supported in a bibliographic revision methodology and in dialogue with some authors that study the conclusive document of the Conference, initially, this article will introduce the innovation promoted by Medellín, suggesting it as an ecclesial charism that could be updated in the contemporary reality. Them, will approach the specificities of the mysticism that is born in that moment.
\end{abstract}

Keywords: Misticism; Interreligious dialogue; Episcopal Conference of Medellín.

Artigo recebido em 20 de agosto de 2017 e aprovado em 28 de agosto de 2018.

Doutor em Ciência da Religião pela Universidade Federal de Juiz de Fora, Brasil (2008). Professor do Programa de Pós-graduação em Ciências da Religião da PUC Minas. País de origem: Brasil. E-mail: fred@pucminas.br

Horizonte, Belo Horizonte, v. 16, n. 50, p. 698-728, maio/ago. 2018 - ISSN 2175-5841 


\section{Introdução}

A Conferência Episcopal de Medellín foi um momento significativo da história da Igreja, sobretudo neste momento de retomada do Vaticano II, juntamente com Medellín, pelo Papa Francisco. Assumindo suas propostas pastoralmente, o Bispo de Roma atual a confirma e a coloca como modelo pastoral e espiritual para a Igreja na contemporaneidade, mesmo distanciando-se historicamente de nossa época, uma vez que completa 50 anos em 2018, tendo sido realizada entre 24 de agosto e 6 de setembro de 1968. Esta distância histórica nos permite análises interessantes e, ao mesmo tempo, possibilita perceber seus impactos, sua recepção e importância. Da mesma forma, a distância temporal permite entrever temáticas que, de alguma maneira e por diversos motivos, não foram abordadas ou, se o foram, tiveram suas abordagens marcadas por concepções e percepções de uma época determinada.

Assim sendo, este artigo quer pensar a Conferência e o Documento conclusivo de Medellín a partir de uma temática que pode ser percebida em suas conclusões, composta de 16 documentos: a mística latino-americana e caribenha. Isto porque entende que, devido à grande importância deste evento para o cristianismo na América Latina, Medellín pode e deve servir de inspirador para pensar questões que hodiernamente nos são significativas, uma vez que se percebe, nas palavras de Brighenti, que "Medellín é um espírito, um ponto de partida" (2017, p. 306) ou, nas palavras de João Décio Passos, é detentor de um "carisma eclesial atual e universal" (2018). E ao fazer isto, busca centrar-se na perspectiva latino-americana, entendendo, com isso, captar certa singularidade e especificidade típicas da cultura deste continente e de como o cristianismo aqui se instituiu: "Como homens latino-americanos, compartilhamos a história de nosso povo. O passado nos configura definitivamente como seres latino-americanos; o presente nos coloca numa conjuntura decisiva e o futuro exige de nós uma tarefa 
criadora do processo do desenvolvimento". (MED, Mensagem aos povos da América Latina, p. 27) ${ }^{1}$

A Conferência do Episcopado Latino Americano e do Caribe em Medellín foi de extrema importância para o cristianismo no continente. No dizer de Pedro Casaldáliga,

Medellín foi, sem dúvida, o Vaticano II da América Latina. Mais avançado que o Vaticano II, porque no Vaticano II a opção pelos pobres foi de uma minoria, quase clandestina, comandada por dom Hélder Câmara. Medellín fez a opção pelos pobres, Medellín fez a opção pelas comunidades, Medellín fez a opção pela militância, a partir da fé. Eu digo sempre que em toda a história da Igreja de América Latina e Caribe não tem tido nenhum acontecimento como Medellín. É o nosso Pentecostes!”. (CASALDÁLIGA apud GODOY; AQUINO JÚNIOR, 2017, p. 7).

Significou uma releitura, uma recepção criativa do Concílio Vaticano II na América Latina, representando um ir além do que estava posto no Vaticano II, revelando seus limites ${ }^{2}$ e adaptando-o e transformando-o contextualmente a partir da realidade latino-americana, de modo que, "Com Medellín, a Igreja na América Latina e no Caribe deixou de ser uma 'Igreja reflexo' do milenar eurocentrismo para desencadear um processo de tessitura de um rosto próprio e de uma palavra própria” (BRIGHENTI, 2017, p. 307).

Mais ainda: Medellín chegou a impactar para além das fronteiras do continente latino-americano, deixando seus rastros na Igreja universal, como no texto de Paulo VI, Evangelii nuntiandi (1975), ou na encíclica Sollicitudo rei socialis (1987), de João Paulo II; ou mesmo estando presente em fala de Bento XVI na abertura da Conferência Episcopal de Aparecida (1997), que após liderar a

\footnotetext{
${ }^{1}$ Esta citação diz respeito às Conclusões da Conferência de Medellín - 1968 - Texto Oficial (edição de 2010), conforme referências no final deste artigo. A partir de agora, sua menção será feita por meio da sigla: MED.

${ }^{2}$ Segundo Aquino Júnior, "'um Concílio universal, mas na perspectiva dos países ricos e da chamada cultura ocidental' (Ellacuría) e, por isso mesmo, um Concílio pouco profético (Comblin) e um Concílio que acabou nos legando 'uma Igreja de classe média' (Aloísio Lorscheider). Se o Concílio teve o mérito incalculável de descentrar a Igreja, de abri-la e lançá-la ao mundo, 'não historicizou devidamente o que era esse mundo, um mundo que devia ter definido como um mundo de pecado e injustiça, no qual as imensas maiorias da humanidade padecem de miséria e injustiça' [Ellacuría]. Não bastava abrir-se ao mundo. Era necessário determinar com maior clareza e precisão que mundo era esse (mundo estruturalmente injusto e opressor) e qual o lugar social da Igreja nesse mundo (mundo dos pobres e oprimidos)" (AQUINO JÚNIOR, 2014, p. 128-129).
}

Horizonte, Belo Horizonte, v. 16, n. 50, p. 698-728, maio/ago. 2018 - ISSN 2175-5841 
elaboração do documento “Alguns aspectos sobre a teologia da libertação” (1984), com uma postura crítica à esta teologia contextual latino-americana, vai afrmar a “opção preferencial pelos pobres”.

Segundo depoimento de Dom Antônio Fragoso, bispo de Crateús entre 1964 e 1998, Medellín foi "um esforço de latino-americanizar o Concílio Vaticano II, uma busca de rosto de Igreja mais encarnada e de um pluralismo eclesial em gestação” (FRAGOSO apud BEOZZO, 2017, p. 21). Pluralismo este associado à ousadia e autonomia episcopal singular que inaugura uma tradição "sem similar na África, Ásia e Europa, [forjando] um modelo de exercício da colegialidade de caráter deliberativo, mais próximo de um Concílio Ecumênico do que de um Sínodo apenas consultivo" (BEOZZO, 2017, p. 23). 3

Ainda segundo Fragoso, significou, também, uma grande inovação no campo pastoral, em que se buscou "olhar a Igreja desde o lugar social dos meios populares (indígenas, afro-americanos, camponeses, 'empobrecidos') e convocar os cristãos a uma ação pastoral transformadora” (FRAGOSO apud BEOZZO, 2017, p. 21). Concepção pastoral que, aliada à uma concepção teológica que nasce da práxis (cf. AQUINO JÚNIOR, 2012), gerou um fermento de criatividade e de ação evangelizadora de alguma maneira inusitável na história do cristianismo. O próprio espírito da Conferência e de seu documento conclusivo assinalam esta perspectiva: "A nova imagem do homem latino-americano exige um esforço criador" (MED, Mensagem aos povos da América Latina, p. 30). Por isto, "Chegou o momento de inventar com imaginação criadora a ação que cabe realizar e que, principalmente,

\footnotetext{
${ }^{3}$ Entretanto, é bom se ter presente a afirmação de Luiz Carlos Sureki, acerca da recepção do Concílio Vaticano II e da II Conferência Geral do Episcopado Latino-americano: "Medellín fecundou setores da Igreja latino-americana, não toda a Igreja latino-americana, assim como o Concílio fecundou setores da Igreja, não a Igreja como um todo. Ao impulso pastoral-espiritual criativo inicial, 'centrífugo', em saída, descentralizante, inovador, logo emergiram forças contrárias, atitudes doutrinais 'centrípetas', de retorno, de centralização, de promoção e manutenção das antigas estruturas eclesiais" (SUREKI, 2018, p. 13).
}

Horizonte, Belo Horizonte, v. 16, n. 50, p. 698-728, maio/ago. 2018 - ISSN 2175-5841 
terá de ser levada a cabo com a audácia do Espírito e o equilíbrio de Deus” (MED, Introdução, 3).4

Da mesma forma, não menos revolucionária é a mística e espiritualidade que nascem de suas concepções teológico-pastorais e as aberturas que pode inspirar e propiciar a partir de suas reflexões, sobretudo, em sua perspectiva pautada pela experiência religiosa. Segundo Manzato, Medellín foi "o tempo da pastoral engajada, da espiritualidade encarnada, da teologia comprometida e do novo jeito de ser Igreja” (MANZATO, 2017, p. 29). Novo jeito de ser Igreja que foi relativamente abandonado nas últimas décadas por diversos setores do catolicismo latino-americano, revelando um processo de "involução eclesial" (AQUINO JÚNIOR, 2018, p. 45)5, caracterizado por autocentramento, clericalismo e pouca preocupação e cuidado com os problemas da humanidade e, sobretudo, dos pobres. Situação esta que ainda hoje encontra resistência na pessoa do Papa Francisco e de sua proposta pastoral para uma "Igreja em saída”, como "hospital de campanha" que chega às "periferias existenciais da humanidade" e com ela dialoga e se torna Boa Nova.

Neste sentido, para podermos pensar em que medida Medellín inspirou e é inspiração para uma mística latino-americana e caribenha, inicialmente iremos discutir o que se pode entender como mística latino-americana, pautados por algumas concepções presentes em Medellín, respondendo à questão de que mística nasce inspirada por este contexto e entendendo que é uma mística em diálogo, ainda mais que, segundo Marcelo Barros (2018, p. 83), o espírito dialogal era manifesto no cenário da Conferência: "entre todas as graças recebidas do Espírito na Conferência de Medellín, uma das mais fortes foi o espírito ecumênico e a experiência de diálogo e unidade intereclesial ali vividos e testemunhados”.

\footnotetext{
${ }^{4}$ É interessante perceber como a dimensão criativa é presente no documento conclusivo da II Conferência do Episcopado LatinoAmericano. A utilização do verbo criar ou a indicação da necessidade de se criar algo, é bastante frequente em todo o texto. Mencionase, dentre outros, a necessidade de "criação de centros urbanos em meios rurais" (MED 1,4), "criação de mecanismos de participação e de legítima representatividade da população" (MED 1,16), "criação de uma ordem nova que assegure a paz no seio de nossos povos" (MED 2,33), "criação de um espírito crítico" (MED 4,4).

${ }^{5}$ Aquino Júnior, no texto mencionado, vai falar em "inverno eclesial" - expressão comum para analisar este período da Igreja Católica -, que ele traduzirá para a cultura nordestina como "seca eclesial".
}

Horizonte, Belo Horizonte, v. 16, n. 50, p. 698-728, maio/ago. 2018 - ISSN 2175-5841 


\section{Uma mística latino-americana e caribenha a partir de Medellín}

Segundo o teólogo Mário de França Miranda (2018, p. 42), a Conferência de Medellín se destacou por sua "força profética", inaugurando um gênero novo de pronunciamentos eclesiais. Em ambiente em que se vivenciou grande liberdade de expressão, diálogo e concórdia nas temáticas abordadas, experimentado como "dias de reflexão e oração comunitária” (MED, Mensagem aos povos da América Latina, p. 34), suas conclusões foram certeiras na abordagem de diversas problemáticas que eram (e ainda são, em muitos casos) presentes na realidade latino-americana. Além do mais, conseguiu dialogar com a comunidade cristã católica e não católica, valendo-se de uma linguagem com menos jargões técnicos e mais voltada para a ação pastoral efetiva e eficaz:

Não basta, certamente, refletir, conseguir mais clarividência e falar. É necessário agir. A hora atual não deixou de ser a hora da "palavra”, mas já se tornou, com dramática urgência, a hora da ação. Chegou o momento de inventar com imaginação criadora a ação que cabe realizar e que, principalmente, terá que ser levada a cabo com a audácia do Espírito e o equilíbrio de Deus. Esta Assembleia foi convidada "a tomar decisões e a estabelecer projetos, somente com a condição de que estivéssemos dispostos a executá-los como compromisso pessoal nosso, mesmo à custa de sacrifícios". ${ }^{6}$ (MED, Introdução, 3).

Tendo em mente estas perspectivas, iremos abordar alguns dos eixos que de alguma maneira sustentam uma mística singular de nosso continente, mística provocada e embebida pela identidade latino-americana: "A América Latina, além de uma realidade geográfica, é uma comunidade de povos com uma história própria, com valores específicos e com problemas semelhantes. A tomada de posições e as soluções devem corresponder a essa história, a esses valores e problemas" (MED, Mensagem aos povos da América Latina, p. 27). E se adotamos a afirmação de Gustavo Gutierrez (1987, p. 39) de que "toda grande espiritualidade está ligada aos grandes movimentos de sua época”, Medellín também desenvolve uma espiritualidade e uma mística associadas ao contexto histórico e cultural

\footnotetext{
${ }^{6}$ Cf. Dom Eugênio de Araújo Sales. A lgreja na América Latina e a promoção humana, 28 de agosto de 1968. Esta referência se encontra no documento de Medellín.
}

Horizonte, Belo Horizonte, v. 16, n. 50, p. 698-728, maio/ago. 2018 - ISSN 2175-5841 
vivenciado no continente latino-americano. Este contexto propicia uma ótica e sensibilidade singulares, que marcarão a forma com que esta mística se manifesta.

\section{Uma mística não dualista, histórica e do cotidiano, centrada no ser humano}

No início do documento conclusivo, nos deparamos com as seguintes posições:

A Igreja latino-americana, reunida na $11^{\text {a }}$ Conferência Geral de seu Episcopado, situou no centro de sua atenção o homem deste continente, que vive um momento decisivo de seu processo histórico. Assim sendo, não se acha desviada, mas voltou-se para o homem, consciente de que para conhecer Deus é necessário conhecer o homem. ${ }^{7}$

Procurou a Igreja compreender este momento histórico do homem latinoamericano à Luz da Palavra, que é Cristo, em quem se manifesta o mistério do homem. ${ }^{8}$ (MED, Introdução, 1)

Esta colocação do ser humano na centralidade do projeto pastoral presente em Medellín é denotação clara de sua concepção teológica que busca a superação de diversos dualismos: natureza / graça; fé / vida; história humana / história da salvação. Neste sentido, elaborou um texto que procura ir além da separação dicotômica entre estes universos, abrindo espaço para uma reflexão teológica que assuma as realidades humanas e temporais, já vislumbradas em sua autonomia no Concílio Vaticano II, como caminhos de salvação, entendendo que “extra mundum nulla salus', fora do mundo dos homens não há salvação" (SCHILLEBEECKX, 1994, p. 30).

Assim se expressa o documento de Medellín:

Sem cair em confusões ou em identificações simplistas, deve-se expressar sempre a unidade profunda que existe entre o plano divino de salvação, realizado em Cristo, e as aspirações do homem; entre a história da salvação e a história humana; entre a Igreja, Povo de Deus, e as comunidades temporais. Entre a ação reveladora de Deus e experiência do homem; entre os dons e carismas sobrenaturais e os valores humanos (MED 8,4).

\footnotetext{
${ }^{7}$ Cf. Paulo VI. Discurso de encerramento do concílio Vaticano II, 7 de dezembro de 1965.

${ }^{8} \mathrm{Cf}$. Concílio Vaticano II. Gaudium et spes, 22.
}

Horizonte, Belo Horizonte, v. 16, n. 50, p. 698-728, maio/ago. 2018 - ISSN 2175-5841 
A separação entre graça e natureza, história humana e história da salvação também anda junta com outra dicotomia: entre fé e vida, que exige um caminho de purificação no sentido de se desvestir das concepções dicotômicas e se buscar um retorno ao Evangelho e a Jesus, para os quais estas distinções não existiam: "Vimos que o mais urgente compromisso de todos os membros e instituições da Igreja católica é purificar-nos no espírito do Evangelho. Devem acabar as separações entre fé e vida" (MED, Mensagem aos povos da América Latina, p. 32). Com isto, chega-se, segundo Paulo VI, à vocação original da América Latina: "vocação de unir numa síntese nova e genial o antigo e o moderno, o espiritual e o temporal, o que outros nos legaram e nossa própria originalidade" 9 (MED, Introdução, 7), de modo que "todo o trabalho temporal adquira seu pleno sentido de liturgia espiritual" (MED 11,18).

Neste sentido, Medellín aponta para "uma modalidade de reflexão teológica peculiar, na qual as reais condições de vida da população não podem ser omitidas na própria compreensão teológica da salvação cristã” (MIRANDA, 2018, p. 43), pois, "Na busca da salvação devemos evitar o dualismo que separa as tarefas temporais da santificação" (MED 1,5). E mesmo a revelação, entendida como gesto salvífico de Deus, que se revela salvando, doando-se à humanidade "para levá-la a participar de sua vida e de sua felicidade” (MIRANDA, 2018, p. 44), é entendida como ocorrendo na vida cotidiana com seus desafios: "a história é prenhe de eventos salvíficos, por mais simples e anônimos que sejam” (MIRANDA, 2018, p. 44).

Supera-se, assim, um viés espiritualista, que cultiva uma "uma espiritualidade sem atenção à encarnação, vivida segundo as preferências pessoais e desenhada sem maiores referências à história, a Jesus ou ao Reino de Deus” (MANZATO, 2017, p. 33), centrada em visões intimistas e na busca exclusiva da salvação da alma. Uma espiritualidade com este rosto, que valoriza "o desenvolvimento de somente algumas dimensões genuínas da vida cristã pode

${ }^{9}$ Cf. Paulo VI. Homilia na ordenação de sacerdotes para a América Latina. 3 de julho de 1966. 
resultar na privatização perigosa da espiritualidade” (GUTIERREZ, 1987, p. 26), gerando um "espiritualismo de fuga” (PUEBLA, 826) e mesmo, segundo o Papa Francisco, um "mundanismo espiritual, dissimulado em práticas religiosas, reuniões infecundas ou discursos vazios" (FRANCISCO, 2013, p. 207).

Assim sendo, a mística que se desenha a partir de Medellín é marcada por "um processo global ao qual não escapa nenhuma dimensão humana, porque exprime, em última instância, a ação salvífica de Deus na história” (GUTIERREZ, 1987, p. 15). Mais ainda, esta mística passa pelos seres humanos, pois "para conhecer a Deus é necessário conhecer ao homem” (PAULO VI, 1965; MED 1,1). ${ }^{10}$

\section{Uma mística integral}

Entretanto, se o ser humano é central em Medellín, ele o é de forma integral, não fragmentado ou possuidor de algumas dimensões especiais em detrimento de outras, menos dignas, mas é concebido em sua totalidade, devendo ser salvo ou embebido na graça divina em todas as dimensões, pois, "Nós, cristãos, não podemos, com efeito, deixar de pressentir a presença de Deus, que quer salvar o homem inteiro, alma e corpo (cf. GS, 13)” (MED, Introdução, 5). Daí a importância de não se desconsiderar o ambiente social, político, econômico e cultural, uma vez que “a obra divina é uma ação de libertação integral e de promoção do homem em toda sua dimensão” (MED 1,4).

Textos como os supracitados indicam um elemento central na concepção místico-espiritual de Medellín:

A espiritualidade não se restringe aos aspectos - assim chamados religiosos: a oração, o culto. Ela não é algo setorial, mas sim, algo total. É toda a existência humana que se põe em marcha, existência pessoal e comunitária. Trata-se de um estilo de vida que dá unidade profunda ao nosso orar, nosso pensar e nosso agir. (GUTIERREZ, 1987, p. 100).

\footnotetext{
${ }^{10}$ Neste mesmo discurso ele insiste neste tipo de afirmação de que "para conhecer o homem, o homem verdadeiro, o homem integral, é necessário conhecer a Deus".
}

Horizonte, Belo Horizonte, v. 16, n. 50, p. 698-728, maio/ago. 2018 - ISSN 2175-5841 
E mesmo a dimensão corpórea dos seres humanos não pode ser excluída das possibilidades da experiência do Sagrado. Neste aspecto, Gustavo Gutierrez, em sua obra "Beber no próprio poço", faz uma interessante discussão acerca da corporalidade humana e sua "carne", que muitas vezes é lida, em certa concepção, como oposta ao "viver segundo o espírito" $(\mathrm{Rm} 8,4)$ paulino. O teólogo peruano entende a carne como a "pessoa humana não somente em parte mas na sua totalidade, considerada do ponto de vista da sua existência física" (GUTIERREZ, 1987, p. 65). Além do mais, acrescenta um aspecto relevante, afirmando que "Na mentalidade semita, a carne é um elemento da solidariedade humana, de laço terrestre. Ser da mesma carne significa pertencer à mesma raça, ao mesmo povo, em última instância, à mesma família humana” (GUTIERREZ, 1987, p. 66).

E trabalhando a ambiguidade carne/espírito, Gutierrez afirmará que "Depositar sua confiança em Deus e agir em consequência é, para Paulo, ser 'espiritual'. Entregar sua vida ao que não é Deus e, em definitivo, fazer de si mesmo a norma suprema de conduta é agir 'carnalmente', o que quer dizer, comportar-se pecadoramente" (GUTIERREZ, 1987, p. 67). Neste sentido, quando se fala em espírito ou carne, se entende o ser humano em sua totalidade quando direcionado para Deus e para o serviço das pessoas ou quando direcionado egoisticamente para si, idolatrando a si mesmo, seu próprio ego, e outras realidades que não lhe abrem à vida, mas a um ensimesmamento problemático, respectivamente.

E na defesa de uma visão integral do ser humano, não podemos deixar fora de nossa compreensão o cosmo e a natureza, criação divina, na qual está inserida toda a humanidade, temática que foi bem explorada na carta encíclica Laudato si, refletindo sobre a questão ecológica a partir da concepção de uma "ecologia integral", que pede uma "educação e espiritualidade ecológicas" (FRANCISCO, 2015). Há que se reconhecer, entretanto, que o texto conclusivo, acerca da perspectiva cosmológica, é bastante antropocêntrico, compreendendo a natureza a serviço do gozo humano: "a fim de que cada homem se realize a si mesmo e goze dos bens da natureza" (MED 13,11); "este dinamismo leva-o [ao ser humano] ao 
domínio cada vez maior da natureza” (MED, Introdução, 4). No entanto, o mesmo texto deixa pistas importantes para que se pense a natureza como lugar teológico para a experiência do Sagrado, uma vez que "toda a criação está envolvida pelo desígnio salvador que abrange a totalidade do homem” (MED 9,4). Se a criação está envolta no desígnio salvífico, ela também é hierofânica.

Desta maneira, as dimensões acima mencionadas são convites para experimentar a Deus de uma outra forma, pois “constituem um 'lugar teológico’ e interpelações de Deus” (MED 7,13), abrindo aos seres humanos nova perspectiva, um "aspecto contemplativo, encontro com Deus no coração mesmo da obra de amor" (GUTIERREZ, 1987, p. 116). Abre-se, então, uma perspectiva de uma contemplação na ação. Ainda mais que "o elemento transcendente não é diretamente acessível, sendo necessária a mediação histórica” (SOBRINO, 1992, p. 12).

\section{Uma mística compassiva, da contemplação na ação e do seguimento de Jesus}

A contemplação na ação, experiência muito significativa e com um caráter singular na América Latina, indica a experiência, também, de uma "mística da compaixão", que se abre profundamente para o sofrimento das pessoas e de todos os seres vivos. Segundo Johann Baptist Metz (2013, p. 94), “nossa paixão por Deus deve se reconhecer e se manter em nossa compaixão, em nossa crescente disposição a uma percepção cada vez mais participativa do sofrimento do outro". ${ }^{11}$

E ao insistir nesta dimensão compassiva diante do sofrimento do outro, Metz vai introduzir categorias como "mística de olhos abertos" que se abre ao outro para o encontro "face a face":

\footnotetext{
${ }^{11}$ Nesta mesma linha, em outra parte de seu texto Metz vai afirmar: O primeiro olhar de Jesus é um olhar messiânico. Ele não se destina, em primeiro lugar, aos pecados dos outros, mas aos seus sofrimentos. [...] Essa sensibilidade messiânica ao sofrimento não tem nada a ver com plangência, com um culto tristonho ao sofrimento, mas tem tudo a ver com uma mística bíblica de justiça: paixão por Deus como empatia pelo sofrimento alheio, como mística prática da compaixão (METZ, 2013, p 19).
} 
Eles são [os cristãos], sobretudo, "místicos de olhos abertos". Sua mística não é uma mística natural, sem face. Ela é muito mais uma mística que busca essa face, que leva esses místicos ao encontro do outro, sofredor, ao encontro da face dos infelizes e vítimas do mundo. Ela obedece, em primeiro lugar, à autoridade dos sofredores. Para essa mística da justiça que busca uma face, a experiência que desabrocha dessa obediência e se define nela torna-se um modelo terreno da proximidade de Deus com seu Cristo: “'Senhor, quando foi que te vimos com fome...' Ao que lhes responderá o rei: 'Em verdade vos digo, cada vez que o fizestes a um desses meus irmãos mais pequeninos, a mim o fizestes"” (cf. Mt 25,31-46). Essa mística da compaixão não tem como objetivo exclusivo uma experiência sem olhos, direcionada ao interior, mas aquela experiência da 'interrupção', introduzida pela situação 'face a face', na relação com o outro. Ela é, ao mesmo tempo, mística e política. Ela é 'mística' na medida em que pode ser o início de uma experiência de Deus, no mínimo uma espécie de ‘atmosfera de Deus'. (METZ, 2013, p. 21).

Já Paul Knitter denominará esta experiência diferenciada de encontro com o Sagrado diante do outro sofredor de "mística do serviço", associando e integrando ação e contemplação:

nós não estamos apenas engajados em ações que resultam da contemplação; não estamos apenas "repassando os frutos da contemplação" (contemplata tradere, como dizem os dominicanos). Antes, estamos engajados na contemplação no momento exato em que agimos e respondemos às vítimas sofredoras desta terra (contemplatione in actione, como dizem os jesuítas). Essa ação é contemplação. (KNITTER, 2005, p. 99).

No entanto, a mística do serviço e da compaixão não nasce, na perspectiva cristã, do nada. Ela se encontra fundada e centrada na mística do seguimento de Jesus. Mística esta que acentua a humanidade de Jesus Cristo, assim como o valor do Jesus histórico como modelo inspirador da vivência cristã e como critério normativo, para a comunidade cristã, de acesso ao Sagrado.

Neste sentido, Jesus Cristo, sua prática e história, se tornam critérios fundamentais e permanentes de discernimento acerca da vida, da história e das relações humanas com o mundo, com a sociedade e o cosmo. Discernimento que pode ser entendido a partir de

Um duplo aspecto ou como uma tarefa dupla: "Por uma parte, pôr em 'crise', submeter à 'prova' nosso dizer e sentir sobre Jesus para não cair numa ilusão e numa alucinação meramente subjetiva e, portanto, 
irreconhecível pela comunidade cristã; e por outra, 'pleitear' (submeter a juízo) nosso modo de estar na vida porque a linguagem muitas vezes é enganadora e mascaradora da realidade". (CATALÁ apud AQUINO JÚNIOR, 2014, p. 62-63).

E o que é central em Jesus, que sobressai de sua prática e que deve se tornar normativo para a comunidade cristã? Sobretudo, dois elementos ocupam lugar fulcral em sua vida: sua relação confiante e profunda com o Abbá e sua entrega ao Reino por meio de seu serviço às pessoas concretas com quem se deparava em seus caminhos. Estas duas dimensões apontam, também, para o lugar da misericórdia, da compaixão e da ternura na vida de Jesus: ternura presente na sua relação com o Pai e as pessoas; compaixão e misericórdia pelo povo, que, muitas vezes, encontrava-se como "ovelhas sem pastor" (Mc 6,34). E a partir de sua misericórdia, Jesus Cristo sintetiza uma série de posturas e valores que a mística de Medellín irá assumir: Ele “não só amou aos pobres, mas também, 'sendo rico se fez pobre', viveu na pobreza, centralizando sua missão no anúncio da libertação aos pobres e fundou sua Igreja como sinal dessa pobreza” (MED 14,7).

\section{Uma mística da conversão que passa pelos empobrecidos}

Entretanto, toda esta experiência de uma mística do serviço, compassiva e de olhos abertos, só é possível a partir da experiência de contínua conversão: "Durante estes dias reunimo-nos na cidade de Medellín pelo espírito do Senhor, para orientar, uma vez mais, as tarefas da Igreja num afã de conversão e serviço" (MED, Mensagem aos povos da América Latina, p. 32). Pois, "para nossa verdadeira libertação todos os homens necessitam de profunda conversão para que chegue a nós o 'Reino de justiça, de amor e de paz”' (MED 1,3).

E conversão aqui precisa ser bem entendida, percebendo que é concebida para além de uma dinâmica da conversão interior, indo além do desprendimento, da austeridade e da pobreza interior, elementos necessários a toda mística, para uma solidariedade, partilha e convivência com o pobre. Assim sendo, a conversão, "afetando as zonas mais profundas do homem, não se limitará ao âmbito da sua intimidade, mas deverá se expressar em atitudes e compromissos, também 
relacionados com as transformações da realidade, como exigência do amor cristão" (DOCUMENTOS DA CONFERÊNCIA EPISCOPAL PERUANA, 1989, p. 109).

Ainda mais que, na perspectiva da mística, esta "só se torna real quando historicizada. E, para historicizá-la, é preciso que aquilo que existe de verdade eterna na importância e necessidade da vida espiritual surja sempre de novo a partir de uma determinada situação histórica” (SOBRINO, 1992, p. 10).

Se esta conversão deve envolver a interioridade humana, pois a "origem de todo desprezo ao homem, de toda injustiça, deve ser procurada no desequilíbrio interior da liberdade humana, que necessita sempre, na história, de um permanente esforço de retificação" (MED 1,3), por outro lado, esta transformação deve se fazer perceber na realidade das estruturas sociais, pois a "conversão do homem, [...] exige imediatamente esta mudança" (MED 1,3).

\section{Como afirma Gustavo Gutierrez,}

A preocupação pelas necessidades materiais do pobre é um elemento da nossa espiritualidade. No gesto correspondente se joga a autenticidade da nossa conversão ao Senhor: "Cristãos que, no compromisso, subscrevemos este documento, nos despojamos do homem velho e encarnamos um homem novo, seguindo a Cristo, Irmão que (Mc 2,21) se desfez de uma espiritualidade como corrente meramente idealista para aceitá-la como força que nos conduz ao compromisso com o vestuário, a educação etc”. ${ }^{12}$ (GUTIERREZ, 1987, p. 115).

E Berdiaeff engrossa a afirmação do teólogo peruano: "Se eu tenho fome, este é um problema material. Se um outro tiver fome, este é um problema espiritual" (BERDIAEFF apud GUTIERREZ, 1987, p. 115).

Desta maneira, a conversão leva à solidariedade que promove ações de serviço, na direção da "promoção humana [que] há de ser a linha de nossa ação em favor do pobre, respeitando sua dignidade pessoal, ensinando-lhe a ajudar-se a si mesmo" (MED 14,11). Isto porque "a Igreja quer servir ao mundo, irradiando sobre

\footnotetext{
${ }^{12}$ Comunidades de Base de Manágua, Nicarágua, 1980, em Nicaragua a un año de la victoria, Lima, CEP, 1980, p. 72.
}

Horizonte, Belo Horizonte, v. 16, n. 50, p. 698-728, maio/ago. 2018 - ISSN 2175-5841 
ele uma luz e uma vida que cura e eleva a dignidade da pessoa humana (cf. GS, 41), consolida a unidade da sociedade (cf. GS, 42) e dá um sentido e um significado mais profundo a toda a atividade dos homens" (MED 1,5).

Além do aspecto acima levantado, a conversão, na perspectiva de Medellín pede uma opção por uma mudança do lugar social da Igreja e de seus membros, o que tem sua máxima na expressão consagrada em Puebla da "opção preferencial pelos pobres", 13 fruto do dinamismo do amor. Isto requer uma revisão das obras tradicionais da Igreja, de sua pastoral, sobretudo, a “pastoral de conservação”, em favor de uma evangelização mais dinâmica e uma "pastoral de conjunto", por meio da qual, "a Igreja da América Latina quer encarnar-se nas realidades concretas de hoje” (MED 12,7), buscando "uma revisão séria e metódica da vida religiosa e da estrutura da comunidade" (MED 12,7).

E o documento vai mais longe ainda, sugerindo o que, mais tarde, será chamado de inserção no meio do povo: "Estimularemos os que se sentem chamados a compartilhar a sorte dos pobres, vivendo com eles e trabalhando com suas próprias mãos"; e no parágrafo seguinte afirma: "Recebam nosso estímulo as [comunidades religiosas] que se sintam chamadas a formar, entre seus membros, pequenas comunidades, encarnadas realmente nos ambientes pobres" (MED 14,16). Ou seja, o documento é permeado, também, por uma mística da encarnação e do serviço silencioso no meio do povo, como Jesus em sua vida escondida em Nazaré, onde, por meio de sua encarnação, foi presença a fecundar a vida do povo e das pessoas a partir "de dentro e de baixo", com seu olhar, inspiração, escuta e acolhimento.

Some-se a esta perspectiva, o pobre - ou melhor, o empobrecido - é visto como lugar teológico do encontro com o Deus libertador, que se preocupa com a

\footnotetext{
${ }^{13}$ O documento de Medellín não se utiliza da expressão "Opção preferencial pelos pobres", embora já acene para ela: "O mandato particular do Senhor, que prevê a evangelização dos pobres, deve levar-nos a uma distribuição tal de esforços e de pessoal apostólico, que deve visar, preferencialmente, os setores mais pobres e necessitados e os povos segregados por uma causa ou outra, estimulando e acelerando as iniciativas e estudos que com esse fim se realizem. Queremos, como bispos, nos aproximar cada vez com maior simplicidade e sincera fraternidade, dos pobres, tornando possível e acolhedor o seu acesso até nós" (MED 14,9).
}

Horizonte, Belo Horizonte, v. 16, n. 50, p. 698-728, maio/ago. 2018 - ISSN 2175-5841 
humanidade e por ela se desvela. Desta maneira, “a irrupção do pobre na sociedade e na Igreja latino-americana é, em última instância, uma irrupção de Deus em nossas vidas. Esta irrupção é o ponto de partida e, ao mesmo tempo, o eixo de uma nova espiritualidade. Por isto, ela indica o caminho que nos conduz ao Deus de Jesus Cristo”. (GUTIERREZ, 1987, p. 41)

Segundo Pablo Richard, a opção preferencial pelos pobres (OPP) "É uma atitude espiritual, pois nela está sempre implícita uma maneira distinta de viver e buscar a Deus; está em jogo um encontro privilegiado com Jesus, que vive historicamente nos pobres (Mt 25). A OPP permite-nos descobrir que a história da salvação passa pela libertação dos pobres e excluídos e pela libertação da terra” (RICHARD, 2006, p. 93).

Esta atitude espiritual supõe todo esvaziamento de si e do egoísmo, pois se pede à Igreja que viva "a pobreza espiritual como atitude de infância espiritual e abertura ao Senhor” (MED 14,4b). Mas também se lhe pede todo esvaziamento das concepções que nascem da exclusão dos pobres, sejam os pobres aqueles que são excluídos do poder econômico, sejam os excluídos de relações étnicas e de gênero igualitárias; seja a própria natureza, que sofre com os desmandos e o espírito dominador e conquistador do poder capitalista. Além disso, uma mística que nasce da conversão e passa pelos empobrecidos, também pede uma atitude: "Denuncia a carência injusta dos bens deste mundo e o pecado que a engendra", além de se comprometer "ela mesma com a pobreza material" (MED 14,5), dimensão fundamental de seu testemunho.

Como afirma o documento conclusivo de Medellín, o compromisso com os pobres e a realidade "exige vivermos uma verdadeira pobreza bíblica que se expresse em manifestações autênticas, sinais claros para nossos povos. Só uma pobreza dessa qualidade fará transparecer a Cristo, Salvador dos homens, e descobrirá a Cristo, Senhor da história” (MED, Mensagem aos povos da América Latina, p. 32). 
Porém, do ponto de vista de uma mística latino-americana, urge, também, se fazer uma experiência de Deus ou do Sagrado a partir dos pobres. De alguma maneira, é esta a singularidade da mística de Medellín: “a possibilidade do seguimento de Jesus se traduz na capacidade de cada um em incorporar-se à experiência espiritual do povo pobre. Isto exige uma conversão espiritual profunda: trata-se de fazer sua a experiência que os pobres têm de Deus e de suas ânsias de plenitude de vida para todos os seres humanos" (GUTIERREZ, 1987, p. 43). ${ }^{14}$

Ou seja, segundo o texto acima, trata-se de uma verdadeira kenosis, por meio da qual se encontra um rosto de Cristo, mediado pelo rosto dos pobres e sofredores. A partir deste lugar de esvaziamento concreto no cotidiano, novas perspectivas sobre a vida e a plenitude querida por Deus para a humanidade se desvelam e se tornam fonte de sonho e utopia. ${ }^{15}$ Mesmo porque, segundo O’Shaughnessy (2016), a mística cristã pode se articular ao redor de dois tipos de definições distintas na tradição judaico-cristã: uma que se centra no encontro contemplativo com Deus; e a outra que se centra em um caráter de discernimento da experiência religiosa: o critério é o amor a Deus e ao próximo. Ou seja, quanto maior a capacidade amorosa, maior é a sinalização do encontro com Deus. E o encontro com Deus mediado pelos pobres e sofredores só acontece junto aos que se dispõem a viver o amor na perspectiva solidária com os despossuídos, carentes e abandonados.

Toda esta perspectiva, também, abre a comunidade e seus agentes para um encontro não com o pobre enquanto categoria abstrata, em geral, "mas, sim, com pessoas de carne e osso. Sem amizade, carinho, sem ternura - por que não dizê-lo (sic)? - não existe gesto de verdadeira solidariedade” (GUTIERREZ, 1987, p. 116).

\footnotetext{
${ }^{14}$ Segundo Kodet, "A espiritualidade cristã deve se orientar para o mundo que Deus ama. Os fiéis são chamados a viver 'em estreitíssima união com os seres humanos de seu tempo. E esforçar-se para inserir-se perfeitamente em seu modo de pensar e sentir (GS, 62)" (KODET, p. 76-77).

${ }^{15}$ Segundo Gustavo Gutierrez, "O encontro com o Senhor, no mais profundo de cada um, não exclui - antes sim, exige - que saibamos também encontrá-lo nas profundezas da miséria em que se encontra o povo pobre de nossos países". (GUTIERREZ, 1987, p. 111).
}

Horizonte, Belo Horizonte, v. 16, n. 50, p. 698-728, maio/ago. 2018 - ISSN 2175-5841 
Por isto, é fundamental se perceber as implicações para a comunidade eclesial: "Que se apresente cada vez mais nítido na América Latina o rosto da Igreja autenticamente pobre, missionária e pascal, desligada de todo poder temporal e corajosamente comprometida com a libertação do homem todo e de todos os homens” (MED 5,15a), com os quais, com seus rostos, está comprometida.

\section{Uma mística diaconal, vivida no dinamismo do amor}

O que mobiliza os sujeitos e os motiva para a compaixão, o serviço, a diaconia e a solidariedade com os pobres é o Amor, cuja vivência conduz à maturidade, uma vez que sair de si, esquecer-se para abrir-se e acolher aos outros em suas alteridades e singularidades, só pode ser vivido por aqueles que vivem na dinâmica do amor:

A síntese do caminho místico do Santo [João da Cruz] reduz-se ao fato de que a maturidade da conversão consiste na maturidade da fé, do amor, e em que o fruto das purificações e "noites" nos deve levar a viver a vida comum motivados e orientados pela fé, pela esperança e pelo amor, e não pelo egoísmo, a sensibilidade ou a pura razão. "A tarde te examinarão sobre o amor". (Ditos de luz e amor, 59). (GALILEA, 1984, p. 41).

Maturidade que se alcança por meio de uma ascese aberta à realidade dura da vida cotidiana do povo pobre e sofredor, aprendendo a servi-lo por meio da convivência próxima e humana, concreta, real.

E é a partir desta realidade que o frade Carmelita Carlos Mesters nos narra sua experiência e busca ascética:

Andando por essas macambiras secas, quase sem vida, monótonas e sem variedade, tive ainda o seguinte pensamento. Nos livros de ascética dizia-se que o fulano que decide empreender a difícil viagem para o encontro com Deus passa por fases difíceis e estéreis, em que tudo lhe causa desgosto e em que Deus parece mais distante do que nunca. Li isso nos livros de dois grandes Santos da nossa Ordem, São João da Cruz e Santa Teresa de Ávila. Mas o mesmo vale para quem decide empreender a difícil viagem para o encontro com o povo, do qual se tinha distanciado por outros tantos motivos. Ele começa a sentir o peso da rotina diária. Desaparece todo o encanto. Não sobra quase nada do romantismo do tempo do noivado. É a rotina pesada do dia-adia. O rosto da noiva aparece agora sem enfeite nenhum, do jeito que é: povo lento, dividido, supersticioso, subserviente aos poderosos, doente, sem iniciativa, sem visão das coisas, dependente do padre. Continuar, assim 
mesmo, a amá-lo por ele mesmo com amor de doação que não espera recompensa, até descobrir, por trás desta casca dura dos seus defeitos, a grande força dos "rios de água viva", isso exige uma ascética igual ou até maior e mais dura do que aquela que está descrita nos livros antigos. E o caminho para o encontro com Deus passa pelo povo, ao menos, para o encontro com o Deus vivo e verdadeiro da Bíblia. Ele é um Deus dos homens, homens bem concretos: Deus de Abraão, Isaaque, Jacó; Deus de Jesus Cristo, e também de Genésio, Adelson, Adelaide e de todo esse povo! O meu Deus também! (MESTERS, 1978, p. 83).

Este tipo de concepção ascética, no entanto, só tem sentido quando aponta para a vivência do amor que implica no desejo de ser solidário, vivendo as angústias e alegrias do povo 16: "Não temos soluções técnicas, nem remédios infalíveis. Queremos sentir os problemas, perceber as exigências, compartilhar as angústias, descobrir os caminhos e colaborar nas soluções” (MED, Mensagem aos povos da América Latina, p. 30).

O amor, além de fundamental para a vida cristã e para a ação transformadora, também é dinamismo que movimenta o cristão em direção à justiça, ao outro e a Deus: "O amor, 'a lei fundamental da perfeição humana, e, portanto, da transformação do mundo' (GS, 38), não é apenas o mandamento supremo do Senhor, é também o dinamismo que deve mover os cristãos a realizar a justiça no mundo" (MED 1,4).

A capacidade de viver no amor é sinal de maturidade humana e espiritual, além de ser abertura para a vivência mística do Encontro e da descoberta do rosto de Deus. Seu aprendizado, no entanto, supõe práticas, lançar-se ao encontro do outro, sair de si para vivenciar uma "Igreja em saída", "samaritana", que se faz "hospital de campanha", para mencionar metáforas caras utilizadas pelo Papa Francisco:

Realmente, a experiência nos ensina que algumas virtudes não se aprendem na capela, mesmo que passemos nela a maior parte do tempo. Não se aprende nela a trabalhar com consciência, nem a amar os outros.

\footnotetext{
${ }^{16}$ Como afirma a Gaudium et spes, 1,1: "As alegrias e as esperanças, as tristezas e as angústias dos homens de hoje, sobretudo dos pobres e de todos aqueles que sofrem, são também as alegrias e as esperanças, as tristezas e as angústias dos discípulos de Cristo; e não há realidade alguma verdadeiramente humana que não encontre eco no seu coração" (VATICANO II, 1983, p. 143); em outra parte deste mesmo documento, assim se pode ler: "Os fiéis vivam portanto muito unidos aos outros homens de sua época e procurem perceber perfeitamente suas maneiras de pensar e de sentir, expressas pela cultura". (VATICANO II, 1983, p. 216).
}

Horizonte, Belo Horizonte, v. 16, n. 50, p. 698-728, maio/ago. 2018 - ISSN 2175-5841 
Para crescer no amor, a coisa mais importante para o espírito, temos que encontrar o amor na vida cotidiana. Não se aprende a amar apenas com a oração. Na oração podemos receber a luz, a coragem e a graça necessárias, mas somente fora da capela, nas situações em que nossa capacidade de amar é colocada à prova, o ser humano pode manifestar seu amor e pode crescer. Sem esquecer o fato evidente de que não se melhora a vida espiritual ocupando-se somente consigo mesmo e com sua própria salvação, mas pensando nos outros e naquilo que pode ser proveitoso a eles. (KODET, 2010, p. 37).

Anselm Grünn também possui um discurso interessante sobre espiritualidade apontando a possibilidade desta vir marcada por elementos narcísicos muitas vezes ocultos sob a aparência de uma busca de Deus ou de um “espírito contemplativo". Neste sentido, ela não aponta para o amor, mas escamoteia a vida humana e seus desafios ao não os enfrentar:

Certa vez um homem me procurou. [...] Contemplação é para ele um caminho de ter tempo para si mesmo; mas ele não aproveita esse tempo para meditar de verdade, para realmente se entregar a Deus. Em última análise, esse girar em torno de si mesmo é sinal de egocentrismo. De tanto soltar o ego, ele nem percebe o quanto alimenta esse ego. Aqui, a contemplação é um girar em torno de um si mesmo narcisista. Ele não encara a vida com seus desafios; antes, foge para uma forma supostamente mais elevada da vida. Ele se sente como algo especial, mas se recusa a enfrentar a vida concreta. [...] A entrega ao trabalho me liberta do meu ego. Mas aquele que interpreta a contemplação como ter tempo para si mesmo, não se liberta de seu ego. Sua espiritualidade se transforma em uma espiritualidade narcisista. (GRÜN, 2015, p. 50-51).

Por sua vez, o amor, quando verdadeiro e maduro, gera humanidade: "Cristo pascal, 'imagem do Deus invisível' $(\mathrm{Cl} 1,15)$, é a meta e o desígnio que Deus estabelece para o desenvolvimento do homem, para que 'alcancemos todos a medida da idade madura da plenitude de Cristo' (Ef 4,13). Por isso, todo 'crescimento em humanidade' (PP, 15, 16 e 18) capacita-nos a 'reproduzir a imagem do Filho" (MED 4,9).

\section{Uma mística das Comunidades de Base}

Cabe ressaltar, ainda, que a partir da proposta de Medellín, há que se superar uma busca místico-espiritual pautada pelo individualismo, embora seja comum pensá-la única e exclusivamente a partir desta ótica.

Horizonte, Belo Horizonte, v. 16, n. 50, p. 698-728, maio/ago. 2018 - ISSN 2175-5841 
Frequentemente, o caminho espiritual é apresentado como uma cultura de valores individuais orientada para o aperfeiçoamento pessoal. A relação com Deus parecia obscurecer a presença das demais e confiava cada cristão à sua própria interioridade. Por isso, a vida espiritual era chamada de vida interior, algo que se vive muito dentro de si. Nela, o importante era o desenvolvimento das virtudes como potencialidades individuais, com pouca ou nenhuma relação com o mundo exterior. Nesta ótica, o que conta é a intenção. Ela é que dá valor aos atos humanos e não seus efeitos externos. (GUTIERREZ, 1987, p. 26).

Medellín reconhece explicitamente que, "Segundo a vontade de Deus, os homens devem santificar-se e salvar-se não individualmente, mas constituídos em comunidade" (MED 6,9). E o caminho apresentado, de alguma maneira, foi o das "Comunidades Cristãs de Base" (MED 8,10). ${ }^{17}$ Locais em que se adquire "um sentido de pertença (de 'nós) que os leve a ser solidários numa missão comum, numa participação ativa, consciente e frutificante, na vida litúrgica e na convivência comunitária” (MED 6,3). Portanto, comunidades não fechadas em si mesmo, mas que, a partir da vivência da fraternidade, se abrem ao serviço à comunidade. Porém, serviço realizado sob uma concepção de ação pastoral que vai além da pastoral de conservação ou das ações evangelizadoras dos movimentos de caráter internacional, com pouca ligação com as igrejas locais ou com uma proposta de pastoral de conjunto (cf. MED 15,1ss), ressignificando, inclusive, o papel das paróquias, que passam, agora, a ser compreendidas como tendo uma função de articular "um conjunto pastoral vivificador e unificador das comunidades de base. Assim, a paróquia tem de descentralizar sua Pastoral no tocante a lugares, funções e pessoas" (MED 15,13).

Assim sendo, as Comunidades Cristãs de Base se tornam locais em que se vive uma experiência espiritual partilhada e na partilha, em que se aprende a experimentar a Deus por meio do encontro e da escuta do outro, que propicia "testemunho de amor e de unidade" (MED 8,10) e que, neste sentido, gera

${ }^{17}$ Ainda não se utilizava o termo, que veio a ser consagrado mais tarde, de Comunidades Eclesiais de Base.

Horizonte, Belo Horizonte, v. 16, n. 50, p. 698-728, maio/ago. 2018 - ISSN 2175-5841 
caminhos de serviço à comunidade: “alcançar a salvação mediante a vivência de fé e de amor" (MED 6,13).

As Comunidades Cristãs de Base - “o primeiro e fundamental núcleo eclesial”, "célula inicial da estrutura eclesial” (MED 15,10) -, neste sentido, apontam para algumas possibilidades. "Abertas ao mundo e inseridas nele, têm de ser fruto da evangelização, assim como sinal que confirma com fatos a Mensagem da Salvação" (MED 8,10), o que indica sua abertura ao mundo e não seu isolamento ou a fuga do mundo. Por outro lado, ela é fruto da evangelização, ou seja, de uma experiência que transforma a vida da comunidade e, ao fazer isto, a transforma em sinal.

Além disso, elas também são fruto do encontro da tradição cristã que foi trazida ao continente latino-americano pelos colonizadores, por um lado, e por outro lado, em diálogo com a tradição da religiosidade popular que aqui se constituiu.

Nesta direção, as comunidades cristãs, por forte influência dos grandes místicos do século XVI espanhol (cf. GALILEA, 1984), acabaram desenvolvendo, de forma latente ou explícita, diversas concepções, tais como:

O senso de Deus e o sentido religioso da visa. A capacidade de oração e de conformidade com a vontade de Deus. O realismo e sabedora cristão diante da condição humana. A valorização do emotivo e afetivo na vida e expressões religiosas. A devoção à humanidade de Cristo sofredor por nós. $\mathrm{O}$ apreço pela Igreja e seu ensinamento (embora seja de maneira geral e implícita) como lugar da vida cristã. (GALILEA, 1984, p. 100).

Associadas à religiosidade popular, que é a religiosidade dos pobres, as pequenas Comunidades Cristãs de Base, segundo Diego Irarrazaval, propiciarão "acompanhar o sofrer e o festejar" (IRARRAZAVAL, 2018, p. 100). Este tipo de religiosidade, muitas vezes de caráter cósmico e natural, possui uma mística popular realista. E a partir dela, propicia relacionamentos em que "a mística do acompanhar caracteriza de modo especial o aliviar o sofrimento de cada dia e o levar a cabo celebrações, segundo os códigos e sensibilidades de cada povo" 
(IRARRAZAVAL, 2018, p. 102). Com fortes implicações na vida cotidiana, nela se escuta e se acolhe o sofrimento do outro, gerando formas partilhadas do carregar a própria cruz, enquanto se ajuda a carregar a do outro.

Mas não é só. Também se partilha nestas comunidades a festa: "Outra vivência crucial é o festejo. [...] Parece-me que o fundamental é poder desfrutar a alegria com os outros e poder agradecer a Deus por ser feliz" (IRARRAZAVAL, 2018, p. 101).

\section{Uma mística profética e libertadora}

Segundo o documento de Medellín, a atuação da Igreja deve estar "corajosamente comprometida com a libertação do homem todo e de todos os homens" (MED 5,15a), que a exemplo da obra divina, "é uma ação de libertação integral e de promoção do homem em toda sua dimensão” (MED 1,4). Esta é a “missão profética da Igreja” (MED 5,13), que denuncia "[a pobreza] como contrária à vontade do Senhor e, muitas vezes, como fruto da injustiça e do pecado dos homens" (MED 14,4) e não fica "indiferente ante as tremendas injustiças sociais existentes na América Latina, que mantêm a maioria de nossos povos numa dolorosa pobreza, que em muitos casos chega a ser miséria desumana” (MED 14,1).

Toda ação profética caminha entre a denúncia e o anúncio. Denúncia a partir de um forte conhecimento do projeto divino que é anunciado e nasce de uma experiência espiritual. Por outro lado, "toda real experiência espiritual gesta profetas e profetisas" (FERRARO \& DORNELAS, 2014, p. 29). Profetas e profetisas que se mobilizam frente as injustiças anelando por libertação, reconhecendo os empobrecidos como sujeitos de libertação e da história, resistentes e não vítimas do sistema ou destinatários de nossas ações assistenciais.

E para que a ação eclesial e de seus agentes de pastoral seja profética e libertadora, faz-se mister que se trabalhe metodicamente. Neste sentido, torna-se 
importante se pensar no método, no planejamento pastoral e nas ações eclesiais de conjunto.

Em relação ao método, o tripé ver-julgar-agir tem sido caracterizado como o método da Teologia da Libertação e é empregado no corpo do documento conclusivo de Medellín, embora sem tanta explicitação metodológica nem nomeação desta metodologia. Nascida no âmbito da Ação Católica francesa, esta metodologia aparece na estrutura de cada um dos 16 documentos do texto conclusivo de Medellín e mesmo de algumas afirmações em que se pode notar claramente a estrutura do método da Ação Católica: o momento histórico "Exige clareza para ver, lucidez para diagnosticar e solidariedade para agir" (MED, Mensagem aos povos da América Latina, p. 29).

Porém, não se há de esquecer que a concepção teológica presente na Teologia da Libertação e também em Medellín supõe uma elaboração do pensamento teológico a partir da práxis e não a partir de uma fragmentação do conhecimento que surge do diálogo com a realidade. ${ }^{18}$

Em termos de mística, esta metodologia aponta para uma mística que nasce do cotidiano e que, ao mesmo tempo, sabe experimentar e avaliar este cotidiano, para, por fim, nele interferir. Portanto, a mística gera um estilo de lidar com o cotidiano e suas lutas e embates, ao mesmo tempo em que gera esperança, persistência e convicções diante dos desafios da transformação da realidade.

\section{Uma mística pautada na leitura engajada da Bíblia}

A mística que a II Conferência Geral do Episcopado Latino-americano gera não pode ser compreendida fora do contexto de uma leitura bíblica engajada. Toda sua linguagem, bem como as metáforas utilizadas, termos técnicos (como Reino de Deus, Amor, Justiça, etc), são retirados da Bíblia e se encontram na busca de

\footnotetext{
${ }^{18} \mathrm{Cf}$. a este respeito, discussão interessante que Aquino Júnior faz acerca do método da Teologia da Libertação: AQUINO JÚNIOR, 2012.
} 
renovação e atualização vividos pelo Vaticano II, que, em sua proposta, busca nas fontes da Revelação e da Tradição, o que é essencial ao cristianismo.

Neste sentido, pode-se encontrar no texto conclusivo uma série de citações bíblicas, cuja função é inspirar a reflexão e ação pastoral cristã, assim como dar fundamento substancial às suas afirmações. Ademais, a Bíblia é colocada como fonte da catequese e da educação na fé, além de ser, também, encontrada na liturgia.

Em termos da catequese, incentiva-se a criatividade no uso da Palavra de Deus: "Não basta, pois, repetir ou explicar a Mensagem. Ao contrário, cumpre reexpressar incessantemente, por novas maneiras, o Evangelho em relação com as formas de existência do homem, tendo em conta os ambientes humanos, étnicos, culturais e guardando sempre fidelidade à Palavra revelada”. (MED 8,15)

Por outro lado, embora ainda em semente e com o suporte dos textos do Vaticano II, sobretudo, da Constituição Dogmática Dei Verbum, Medellín indica e aponta para uma presença dinâmica da Bíblia no seio das comunidades cristãs. Nesta inspiração é que nascerão os Círculos Bíblicos, que discutem a vida e seus problemas a partir da Palavra de Deus e pensam a Palavra a partir das suas vidas, numa circularidade rica entre texto, contexto e questões vitais, gerando uma hermenêutica diferenciada, profundamente relacionada com a vida do povo e as questões existenciais e sociais por ele vividas. Neste sentido, com este tipo de leitura se procura aprofundar na Revelação, com abertura a novas chaves hermenêuticas para a compreensão da Bíblia e da vida:

A tomada de consciência da mensagem cristã se faz aprofundando cada vez mais a compreensão autêntica da Verdade revelada. Essa tomada progressiva de consciência, porém, cresce na medida do surgimento das experiências humanas, individuais e coletivas. Por isso, a fidelidade da Igreja à Revelação tem de ser e é dinâmica. (MED 8,5).

Assim, pautados nesta concepção de recepção criativa e engajada da Bíblia, tanto na educação na fé, quanto na perspectiva litúrgico-orante e com fortes 
acentos de diálogo entre vida e fé, na América Latina se desenvolverá um método singular de leitura e hermenêutica bíblica, associado a nomes como Carlos Mesters, Milton Schwantes, José Comblin, Gilberto Gorgulho, Jorge Pixley e Pablo Richard.

Nesta inspiração, retoma o Êxodo e a tradição profética, descobrindo na Bíblia um Deus que toma partido em favor dos empobrecidos e excluídos. Um Deus que quer estabelecer a Justiça, o Direito e a Paz; que não quer os sacrifícios e holocaustos, mas a misericórdia (Os 6,6; Is 1,11ss).

\section{Uma mística que discerne os "Sinais dos Tempos"}

Por fim, é importante ressaltar que Medellín aponta para uma mística que se pauta pelo discernimento dos "sinais dos tempos". Com fortes acentos bíblicos, a noção de sinais dos tempos já aparece na Gaudium et spes, 11: "o Povo de Deus esforça-se por discernir nos acontecimentos, nas exigências e nas aspirações de nossos tempos, em que participa com os outros homens, quais sejam os sinais verdadeiros da presença ou dos desígnios de Deus” (VATICANO II, 1983, p. 153).

Medellín segue na mesma trilha:

Cremos que estamos numa era histórica. Exige clareza para ver, lucidez para diagnosticar e solidariedade para agir. À luz da fé que professamos como fiéis, fizemos um esforço para descobrir o plano de Deus nos "sinais de nossos tempos". Interpretamos que as aspirações e clamores da América Latina são sinais que revelam a orientação do plano divino operante no amor redentor de Cristo que funda estas aspirações na consciência de uma solidariedade fraterna. (MED, Mensagem aos povos da América Latina, p. 29).

No sentido do texto acima, fica clara a concepção de que se lê os sinais do Sagrado ou de Deus nos sinais da história e dos acontecimentos que cercam a vida das pessoas e nações que compõem o continente latino-americano e o Caribe. Além disso, estes sinais são mediados pelas condições reais de vida da população, sobretudo, dos mais pobres e dos excluídos, pois "não pode ser a-temporal nem ahistórica [os sinais dos tempos], que em nosso continente se manifestam sobretudo na área social” (MED 7,13). Lendo neles o plano divino da salvação - pois eles 
“constituem um 'lugar teológico’ e interpelações de Deus” (MED 7,13) - a partir da hermenêutica baseada no método Ver-Julgar-Agir.

Neste sentido, a perspectiva do Ver visa ajudar a Ler o mundo de uma forma mais aprofundada, indo além da superfície e tentando desconstruir as ideologias presentes na vida social que impedem de ver com clareza. E isto não é visto de forma dualista em relação às vivências místicas, pois, com este olhar para além das aparências se entende penetrar com mais qualidade na realidade da vida e das condições de vida das pessoas. Penetrando nesta profundidade se encontra o Espírito de Deus falando e se manifestando.

Para melhor entender o que se vê, além das mediações socioanalíticas, também se estabelecem critérios para avaliar e julgar a realidade, sobretudo, a partir de um olhar provocado pela realidade dos empobrecidos e por suas vidas concretas sobre a Palavra de Deus e a Tradição eclesial.

Por fim, é uma mística que não fica apenas no conceitual, no abstrato, mas valoriza-se uma mística que se faz presença atuante na vida dos que precisam de algum apoio, ajuda, colaboração ou serviço da comunidade cristã: "Em todos esses ambientes, a evangelização deve orientar-se para a formação de uma fé pessoal, adulta, interiormente formada, operante e constantemente em confronto com os desafios da vida atual” (MED 7,13). Neste sentido, pode-se retomar a concepção de Paul Knitter: trata-se de uma mística do serviço, que se torna eficaz por meio da ação e que, nesta ação em favor dos empobrecidos, excluídos e necessitados, tomando seu partido, crê-se encontrar Deus e com Ele entrar em comunhão.

\section{Conclusão}

Após ter revisitado uma série de textos presentes no documento conclusivo da II Conferência Geral do Episcopado Latino-Americano, pode-se ver que esta Conferência, além de ser uma releitura do Concílio Vaticano II, de forma ecumênica e engajada, também possibilitou ao cristianismo desenvolver um rosto 
latino-americano, expondo sua singularidade na forma de ler a Bíblia e a Tradição perante o cristianismo mundial. Ao fazer isto, também desenvolve uma mística singular, que, longe de se afastar da tradição cristã, retoma elementos que lhe são essenciais, porém, numa perspectiva singular e original, com uma ênfase própria.

Sua capacidade de dialogar com os povos destas terras e de propor um diálogo com a realidade destes povos, marcados por situações de empobrecimento, exploração e exclusão social ainda hoje, apontam para uma concepção de mística que interage com a vida, com o cotidiano e que está longe de ser uma fuga mundi, embora este conceito, quando bem entendido no contexto de sua época, faça certo sentido e não deva ser jogado fora. Mas, quando compreendido como um fugir das realidades terrenas e não se comprometer com sua transformação, acaba desviando-se do foco do próprio evangelho, que propõe que os cristãos sejam sal e luz do mundo, capazes de dar gosto e sabor a uma série de estruturas caducas e que geram injustiça, exclusão e morte, não sendo capazes de produzir vida.

Neste sentido, Medellín inova, propõe alternativas e é extremamente atual, podendo ser entendido como possuidor de universalidade, enquanto adaptável à realidades e culturas distintas. Cabe, portanto, debruçar-se sobre seu documento conclusivo, sua história e recepção na América Latina, assim como estudar seus impactos para além da América Latina e o Caribe. Ao mesmo tempo, cabe aceitar suas provocações, seu dinamismo profético, sua mística e espiritualidade neste momento desafiador de nossa história, em que a situação no continente latinoamericano e no catolicismo nos pede discernimento; momento em que a própria Igreja Católica, por sua vez, através de sua liderança maior, o Papa Francisco, caminha em uma agenda propositiva no sentido de uma eclesiologia e uma ação pastoral que tem muito do rosto de Medellín. Fica-nos o convite. E que o desejo de conversão e de transformação sejam capazes de nos mover em direção a caminhos novos e inovadores. 


\section{REFERÊNCIAS}

AQUINO JÚNIOR, Francisco. Teoria teológica: práxis teologal. Sobre o método da Teologia da Libertação. São Paulo: Paulinas, 2012.

AQUINO JÚNIOR, Francisco. Viver segundo o espírito de Jesus Cristo. Espiritualidade como seguimento. São Paulo: Paulinas, 2014.

AQUINO JÚNIOR, Francisco. 50 anos de Medellín - 5 anos de Francisco: perspectivas teológico-pastorais. Perspectiva Teológica, Belo Horizonte, v. 5o, n. 1, p. 41-58, Jan./Abr. 2018.

BAPTISTA, Paulo Agostinho Nogueira. Religião, política e teologia da libertação: trajetórias e desafios. Revista Pistis e Praxis, Teologia e Pastoral, Curitiba, v. 6, n. 1, p. 229-254, jan./abr. 2014. Disponível em:<http://www2.pucpr.br/reol/pb/index.php/pistis?dd99=issue\&ddo=427>. Acesso em: 06 jun. 2018.

BARROS, Marcelo. O sopro do Espírito em Medellín. A ecumenicidade na conferência e nos documentos de Medellín. Convergência. Ano LIII, $\mathrm{n}^{0}$ 513, julho e agosto de 2018, p. 82-95.

BEOZZO, José Oscar. Medellín: seu contexto em 1968 e sua relevância 50 anos depois. In: GODOY, Manoel; AQUINO JÚNIOR, Francisco de. 50 anos de Medellín: revisitando os textos, retomando o caminho. São Paulo: Paulinas, 2017.

BÍBLIA DE JERUSALÉM. São Paulo: Paulus, 2002.

BOFF, Clodovis. A originalidade histórica de Medellín. Disponível em:

<http://servicioskoinonia.org/relat/203p.htm>. Acesso em: 20 de jun. 2018.

BRIGHENTI, Agenor. Desafios e horizontes de Medellín: para a configuração e organização da Igreja hoje. In: GODOY, Manoel; AQUINO JÚNIOR, Francisco de. 50 anos de Medellín: revisitando os textos, retomando o caminho. São Paulo: Paulinas, 2017.

CONSELHO EPISCOPAL LATINO AMERICANO. Conclusões da Conferência de Medellín - 1968. Texto oficial. São Paulo: Paulinas, 2010.

CONSELHO EPISCOPAL LATINO AMERICANO. Conclusões da Conferência de Puebla. Evangelização no presente e no futuro da América Latina. Texto oficial. São Paulo: Edições Paulinas, 1979.

DOCUMENTOS DA CONFERÊNCIA EPISCOPAL PERUANA. 1979-1989. Lima: VE, 1989.

DORNELAS, Nelito Nonato. CEBs e espiritualidade profético-libertadora. In: FERRARO, B. \& DORNELAS, N. N. (Org.). CEBs. Raízes e frutos ontem e hoje. Brasília: Scala Editora, 2014 .

Horizonte, Belo Horizonte, v. 16, n. 50, p. 698-728, maio/ago. 2018 - ISSN 2175-5841 
FRANCISCO, Papa. Evangelii gaudium. São Paulo: Paulinas, 2013.

FRANCISCO, Papa. Laudato si. Sobre o cuidado com a casa comum. São Paulo: Paulinas, 2015 .

GALILEA, Segundo. As raízes da espiritualidade latino-americana. São Paulo: Paulinas, 1984.

GODOY, Manoel; AQUINO JÚNIOR, Francisco de. 50 anos de Medellín: revisitando os textos, retomando o caminho. São Paulo: Paulinas, 2017.

GRÜN, Anselm. Não desperdice sua vida. Petrópolis: Vozes, 2015.

GUTIÉRREZ, Gustavo. Beber no próprio poço. $4^{\mathrm{a}}$ ed. Petrópolis: Vozes, 1987.

GUTIERREZ, Gustavo. Teologia da libertação: perspectivas. 6ª ed. Petrópolis: Vozes, 1986.

IRARRAZAVAL, Diego. Povos com mística terrena. In: SOUZA, N. \& SBARDELOTTI, E. (Org.). Medellín. Memória, profetismo e esperança na América Latina. Petrópolis: Vozes, 2018.

KNITTER, Paul. Religiões, misticismo e libertação. Um diálogo entre a teologia da libertação e a teologia das religiões. In: TOMITA, Luiza; BARROS, Marcelo; VIGIL, José María (Org.). Pluralismo e libertação. Por uma teologia latino-americana pluralista a partir da fé cristã. São Paulo: Loyola, 2005, p. 89 - 105.

KODET, Vojtech. Marta e Maria. Uma leitura um pouco diferente da ação e da contemplação. Petrópolis: Vozes, 2010.

LORA, Cecílio. Del Concílio a Medellín, hoy. Horizonte, Belo Horizonte, v. 9, n. 24, p. 1233-1245, dez. 2011.

MANZATO, Antônio. A situação eclesial atual. In: GODOY, Manoel; AQUINO JÚNIOR, Francisco de. 50 anos de Medellín: revisitando os textos, retomando o caminho. São Paulo: Paulinas, 2017.

MATOS, Henrique Cristiano José de. CEBs. Uma interpelação para o ser cristão hoje. São Paulo: Paulinas, 1985.

MESTERS, Carlos. Seis dias nos porões da humanidade. Petrópolis: Vozes, 1978.

METZ, Johann Baptist. Mística de olhos abertos. São Paulo: Paulus, 2013.

O'SHAUGHNESSY, Laura Nuzzi. "God Speaks from within History”. The Challenging Witness of Liberation Theology. Latin American Research Review. 51(3):227-240, January, 2016. 
PAULO VI. Discurso do Papa Paulo VI na última sessão pública do Concílio Vaticano II. 7 de Dezembro de 1965. In: http://w2.vatican.va/content/paul-

vi/pt/speeches/1965/documents/hf_p-vi_spe_19651207_epilogo-concilio.html. Acesso em: 18/07/2018.

MIRANDA, Mário de França. A teologia de Medellín. In: SOUZA, N.; SBARDELOTTI, E. (Org.). Medellín. Memória, profetismo e esperança na América Latina. Petrópolis: Vozes, 2018.

PASSOS, João Décio. 50 anos de Medellín - Carisma vivo na história em mudança. In: SOUZA, N.; SBARDELOTTI, E. (Org.). Medellín. Memória, profetismo e esperança na América Latina. Petrópolis: Vozes, 2018.

RICHARD, Pablo. Força ética e espiritual da teologia da libertação. São Paulo: Paulinas, 2006.

SCHILLEBEECKX, Edward. História humana, revelação de Deus. São Paulo: Paulus, 1994 .

SILVA, Rafael Rodrigues. Medellín e a leitura da Bíblia. In: GODOY, Manoel; AQUINO JÚNIOR, Francisco de. 50 anos de Medellín: revisitando os textos, retomando o caminho. São Paulo: Paulinas, 2017.

SOBRINO, Jon. Espiritualidade da libertação. São Paulo: Loyola, 1992.

SOUZA, Carlos Frederico Barboza de. Pe. Cícero Romão Batista: por uma mística sertaneja do Cariri. Pistis e Praxis, Curitiba, v. 10, n. 2, 338-374, maio/ago. 2018.

SOUZA, N.; SBARDELOTTI, E. (Org.). Medellín. Memória, profetismo e esperança na América Latina. Petrópolis: Vozes, 2018.

SUREKI, Luiz Carlos. Perspectiva Teológica. Belo Horizonte, v. 50, n. 1, p. 11-17, jan./abr. 2018.

TEIXEIRA, Faustino. O resgate da espiritualidade no cotidiano. In: PANASIEWICZ, R. \& VITÓRIO, J. Espiritualidades e dinâmicas sociais. São Paulo: Paulinas, 2014.

VATICANO II. Compêndio do Vaticano II. Constituições, decretos, declarações. Petrópolis: Vozes, 1983.

V. V. A. A. $2^{\circ}$ Dossiê sobre o $\mathbf{1 3}^{\mathbf{0}}$ Intereclesial. Iser Assessoria, 2014. In: <www.amerindiaenlared.org/uploads/adjuntos/1394214782_attach99.doc >. Acesso em: $02 / 02 / 2018$.

VIGIL, José María; CASALDÁLIGA, Pedro. Espiritualidade da libertação. Petrópolis: Vozes, 1993. 